\title{
MATING SPEED AND DURATION OF COPULATION IN DROSOPHILA PSEUDOOBSCURA
}

\author{
P. A. PARSONS and D. KAUL \\ Department of Genetics, University of Melbourne, Victoria, Australia
}

Received 6.viii. $6_{5}$

\section{INTRODUCTION}

SPIESS and Langer ( $1964 a$ ) found mating speed differences for different homokaryotypes in $D$. pseudoobscura such that AR karyotypes mated the most rapidly, followed in order by ST, CH, TL and PP. Kaul and Parsons (1965) found the karyotype of the male to be of critical importance in determining both mating speed and duration of copulation for all possible combinations between the three karyotypes $\mathrm{ST} / \mathrm{ST}, \mathrm{ST} / \mathrm{CH}$ and $\mathrm{CH} / \mathrm{CH}$. For mating speeds in the males ST/ST was fastest, followed by ST/CH and $\mathrm{CH} / \mathrm{CH}$, while durations of copulation were in the reverse order. Because of the large difference found by Spiess and Langer (1964a) between AR and PP homokaryotypes, it was decided to study mating speeds and durations of copulation for all possible combinations between AR/AR, AR/PP and $\mathrm{PP} / \mathrm{PP}$ karyotypes at two temperatures, $20^{\circ} \mathrm{C}$. and $25^{\circ} \mathrm{C}$.

\section{METHOD}

The technique was essentially the same as that used by Kaul and Parsons (1965). After separation at eclosion, flies were stored singly in vials. At 4 days a single male was shaken into a vial with a single female and observed until copulation began. The time in minutes for this to occur is the mating speed. The recording of the duration of copulation followed immediately after. Any pairs not mating in $\leqslant 30$ minutes were recorded as unmated.

The larvae used for the mating experiments were cultured at a density of 40 larvae per vial at $20^{\circ} \mathrm{C}$. and $25^{\circ} \mathrm{C}$. respectively.

Fifty trials split into two replicates of 25 were carried out for each of the 9 possible karyotypic combinations for flies at both temperatures.

\section{RESULTS}

In table I the mean numbers mating out of 25 for the two temperatures in 5 minutes are given. The following observations can be made directly on the table:

(I) Fewer matings occurred at $25^{\circ}$ C. than at $20^{\circ}$ C. This temperature difference is significant (table 2) and is maintained at 30 minutes.

(2) The marginal means show that the karyotype of the females is more important than that of the males in determining the mating frequency especially at $25^{\circ} \mathrm{C}$. Analyses of variance for the two temperatures (tables 2 and 3) confirm this, and although there is a significant effect due to the karyotype of 
the males at $20^{\circ} \mathrm{C}$. (table 3 ), it is far smaller than that due to the karyotype of the females.

(3) The marginal means for the karyotype of the females show that the main difference between the two temperatures is a low $\mathrm{PP} / \mathrm{PP}$ mating frequency at $25^{\circ} \mathrm{C}$. compared with $20^{\circ} \mathrm{C}$., and

TABLE $I$

Mean number of matings out of 25 in 5 minutes for $A R / A R, A R / P P$ and $P P / P P$ karyotypes at $20^{\circ} \mathrm{C}$. and $25^{\circ} \mathrm{C}$.

\begin{tabular}{|c|c|c|c|c|c|}
\hline \multicolumn{2}{|c|}{$20^{\circ} \mathrm{C}$. Male karyotypes } & \multirow{2}{*}{$\begin{array}{l}\text { AR/AR } \\
\text { I I } \\
13.5 \\
12.5\end{array}$} & \multirow{2}{*}{$\begin{array}{l}\mathrm{AR} / \mathrm{PP} \\
12 \\
17.5 \\
21\end{array}$} & \multirow{2}{*}{$\begin{array}{r}\mathrm{PP} / \mathrm{PP} \\
7.5 \\
17.5 \\
21.5\end{array}$} & \multirow[b]{2}{*}{$\begin{array}{l}10 \cdot 17 \\
16 \cdot 17 \\
18 \cdot 33\end{array}$} \\
\hline Female karyotypes & $\begin{array}{l}\mathrm{AR} / \mathrm{AR} \\
\mathrm{AR} / \mathrm{PP} \\
\mathrm{PP} / \mathrm{PP}\end{array}$ & & & & \\
\hline & & 12.33 & 16.83 & 15.5 & $14 \cdot 89$ \\
\hline
\end{tabular}

\begin{tabular}{|c|c|c|c|c|c|}
\hline \multicolumn{2}{|c|}{$25^{\circ} \mathrm{C}$. Male karyotypes } & \multirow{2}{*}{ 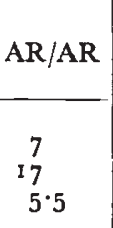 } & \multirow{2}{*}{$\begin{array}{l}\mathrm{AR} / \mathrm{PP} \\
10.5 \\
16 \\
10.5\end{array}$} & \multirow{2}{*}{$\begin{array}{r}\mathrm{PP} / \mathrm{PP} \\
\begin{array}{r}7.5 \\
8.5 \\
8\end{array}\end{array}$} & \multirow[b]{2}{*}{$\begin{array}{r}8 \cdot 33 \\
17 \cdot 17 \\
8\end{array}$} \\
\hline Female karyotypes & $\begin{array}{l}\mathrm{AR} / \mathrm{AR} \\
\mathrm{AR} / \mathrm{PP} \\
\mathrm{PP} / \mathrm{PP}\end{array}$ & & & & \\
\hline & & $9 \cdot 83$ & $12 \cdot 33$ & $11 \cdot 33$ & II 17 \\
\hline
\end{tabular}

TABLE 2

Analysis of variance of the number mating out of 25 in 5 minutes (after applying the angular transformation)

\begin{tabular}{|c|c|c|c|c|}
\hline Source of variation & d.f. & m.s. & $\mathbf{F}$ & Probability \\
\hline $\begin{array}{l}\text { Female karyotypes } \\
\text { Male karotypes }: \\
\text { Temperatures } \\
\text { Females } \times \text { males } \\
\text { Females } \times \text { temperatures } \\
\text { Males } \times \text { temperatures } \\
\text { Females } \times \text { males } \times \text { temperatures } \\
\text { Error }\end{array}$ & $\begin{array}{r}2 \\
2 \\
1 \\
4 \\
2 \\
2 \\
4 \\
4\end{array}$ & $\begin{array}{l}929 \cdot 55 \\
241 \cdot 43 \\
782 \cdot 51 \\
122 \cdot 36 \\
658 \cdot 48 \\
20 \cdot 36 \\
52 \cdot 25 \\
33 \cdot 11\end{array}$ & $\begin{array}{r}28 \cdot 08 \\
7 \cdot 29 \\
23 \cdot 64 \\
3 \cdot 70 \\
19 \cdot 89 \\
0 \cdot 61 \\
1 \cdot 58\end{array}$ & $\begin{array}{l}<0 \cdot 001 \\
<0 \cdot 05 \\
<0 \cdot 001 \\
<0 \cdot 05 \\
<0 \cdot 001\end{array}$ \\
\hline
\end{tabular}

a somewhat lower AR/AR frequency at $25^{\circ} \mathrm{C}$. than at $20^{\circ} \mathrm{C}$. Hence there is strong heterokaryotype advantage for females at $25^{\circ} \mathrm{C}$. but not at $20^{\circ} \mathrm{C}$. It is not therefore surprising that there is a significant female $\times$ temperature interaction (table 2).

These various trends still occur for the numbers mating out of 25 in 30 minutes. 
In table 4 are the mean durations of copulation. The entries in the table are based on 22 observations, since there were 22 observations for the combination of $\mathrm{PP} / \mathrm{PP} q \times \mathrm{AR} / \mathrm{AR} \delta^{*}$ at $25^{\circ} \mathrm{C}$. in 30 minutes and more for all other contrasts. The excess over 22 for the other

TABLE 3

Analysis of variance of the number mating out of 25 in 5 minutes at $20^{\circ} \mathrm{C}$. and $25^{\circ} \mathrm{C}$. separately (after applying the angular transformation)

\begin{tabular}{|c|c|c|c|c|c|}
\hline \multirow{2}{*}{ Source of variation } & \multirow{2}{*}{ d.f. } & \multicolumn{2}{|c|}{$20^{\circ} \mathrm{C}}$. & \multicolumn{2}{|c|}{$25^{\circ} \mathrm{C}}$. \\
\hline & & m.s. & F & m.s. & F \\
\hline $\begin{array}{l}\text { Female karyotypes } \\
\text { Male karyotypes } \\
\text { Males } \times \text { females } \\
\text { Error }\end{array}$ & $\begin{array}{l}2 \\
2 \\
4 \\
9\end{array}$ & $\begin{array}{c}66_{3} \cdot 10 \\
199 \cdot 43 \\
13^{2} \cdot 35 \\
3^{8} \cdot 7\end{array}$ & $\begin{array}{c}17 \cdot 14^{* * *} \\
5 \cdot 15^{*} \\
3 \cdot 4^{2}\end{array}$ & $\begin{array}{l}924 \cdot 93 \\
62 \cdot 35 \\
42 \cdot 26 \\
27 \cdot 5\end{array}$ & $\begin{array}{c}33 \cdot 6 \mathrm{I} * * * \\
2 \cdot 27 \\
\mathrm{I} \cdot 54\end{array}$ \\
\hline
\end{tabular}

TABLE 4

Mean durations of copulation (minutes) at $20^{\circ} \mathrm{C}$. and $25^{\circ} \mathrm{C}$.

\begin{tabular}{|c|c|c|c|c|}
\hline${ }^{20^{\circ} \mathrm{C} .}$ Karyotype of males & $\mathrm{AR} / \mathrm{AR}$ & $\mathrm{AR} / \mathrm{PP}$ & $\mathrm{PP} / \mathrm{PP}$ & \\
\hline $\begin{aligned} \text { Karyotype of females } & \text { AR/AR } \\
& \text { AR/PP } \\
& \text { PP/PP }\end{aligned}$ & $\begin{array}{l}4 \cdot 05 \\
4 \cdot 07 \\
4 \cdot 34\end{array}$ & $\begin{array}{l}4 \cdot 27 \\
4 \cdot 30 \\
4.61\end{array}$ & $\begin{array}{l}4 \cdot 00 \\
3 \cdot 9^{8} \\
3 \cdot 75\end{array}$ & $\begin{array}{l}4 \cdot 1 \mathrm{I} \\
4 \cdot \mathrm{II} \\
4 \cdot 23\end{array}$ \\
\hline & $4 \cdot I 5$ & $4 \cdot 39$ & $3.9 \mathrm{I}$ & $4 \cdot 15$ \\
\hline
\end{tabular}

\begin{tabular}{|c|c|c|c|c|}
\hline $25^{\circ} \mathrm{C}$. & $\mathrm{AR} / \mathrm{AR}$ & $\mathrm{AR} / \mathrm{PP}$ & $\mathrm{PP} / \mathrm{PP}$ & \\
\hline $\begin{array}{r}\text { Karyotypes of females AR/AR } \\
\text { AR/PP } \\
\text { PP/PP }\end{array}$ & $\begin{array}{l}6 \cdot 00 \\
4 \cdot 93 \\
4 \cdot 80\end{array}$ & $\begin{array}{l}4 \cdot 34 \\
4 \cdot 50 \\
4 \cdot 70\end{array}$ & $\begin{array}{l}4 \cdot 05 \\
5 \cdot 57 \\
4 \cdot 59\end{array}$ & $\begin{array}{l}4 \cdot 80 \\
5 \cdot 00 \\
4 \cdot 70\end{array}$ \\
\hline & $5^{.24}$ & $4 \cdot 5^{2}$ & $4 \cdot 73$ & $4 \cdot 83$ \\
\hline
\end{tabular}

contrasts was removed by a randomisation procedure. The following observations can be made:

(I) The duration of copulation is greater at $25^{\circ} \mathrm{C}$. than at $20^{\circ} \mathrm{C}$. This is confirmed by an analysis of variance (table 5).

(2) At both temperatures the marginal means for the karyotyne of the males are more variable than for females as is confirmed by the larger $\mathrm{F}$ values for male karyotypes in tables 5 and 6 . 
The male karyotype $\mathrm{PP} / \mathrm{PP}$ has a shorter duration of copulation than $\mathrm{AR} / \mathrm{AR}$ at both temperatures.

(3) The marginal means for the karyotype of the males show that the main difference between temperatures is that the durations of copulation of the homokaryotypes are increased relatively more than the heterokaryotype at $25^{\circ} \mathrm{C}$., so that at $25^{\circ} \mathrm{C}$. the heterokaryotype has the shortest duration of copulation. This explains the significant male $\times$ temperature interaction in table 5. A final distinction between temperatures is a significant female $\times$ male interaction at $25^{\circ} \mathrm{C}$. but not at $20^{\circ} \mathrm{C}$.

TABLE 5

Analysis of variance of durations of copulation

\begin{tabular}{|c|c|c|c|c|c|c|}
\hline \multicolumn{3}{|c|}{ Source of variation } & d.f. & m.s. & $\mathbf{F}$ & Probability \\
\hline Female karyotypes & . & . & 2 & 0.43 & $0 \cdot 22$ & \\
\hline Male karyotypes & . & . & 2 & $4 \cdot 77$ & $2 \cdot 4 \mathrm{I}$ & \\
\hline Temperatures. & . & . & 1 & 45.68 & 23.04 & $<0.001$ \\
\hline Females $\times$ males & . & . & 4 & $5 \cdot 77$ & $2 \cdot 9 \mathrm{I}$ & $<0.05$ \\
\hline Females $\times$ temperatur & es & . & 2 & $\mathrm{I} \cdot 49$ & $0 \cdot 75$ & \\
\hline Males $\times$ temperatures & . $\quad$. & . & 2 & $8 \cdot 29$ & $4 \cdot 18$ & $<0.05$ \\
\hline Female $x$ males $\times$ tem & iperatures & . & 4 & $5 \cdot 88$ & $2 \cdot 96$ & $<0.05$ \\
\hline Error & . $\quad$. & . & $37^{8}$ & $1 \cdot 9^{8}$ & & \\
\hline
\end{tabular}

TABLE 6

Analysis of variance of durations of copulation at $20^{\circ} \mathrm{C}$. and $25^{\circ} \mathrm{C}$. separately

\begin{tabular}{|c|c|c|c|c|c|}
\hline \multirow{2}{*}{ Source of variation } & \multirow{2}{*}{ d.f. } & \multicolumn{2}{|c|}{$20^{\circ} \mathrm{C}$. } & \multicolumn{2}{|c|}{$25^{\circ} \mathrm{C}$. } \\
\hline & & $\mathrm{m}, \mathrm{s}$ & $\mathbf{F}$ & m.s. & $\mathbf{F}$ \\
\hline $\begin{array}{l}\text { Female karyotypes } \\
\text { Male karyotypes } \\
\text { Females } \times \text { males } \\
\text { Error }\end{array}$ & $\begin{array}{r}2 \\
2 \\
4 \\
189\end{array}$ & $\begin{array}{l}0 \cdot 34 \\
3 \cdot 88 \\
0 \cdot 73 \\
1 \cdot 58\end{array}$ & $\begin{array}{l}0 \cdot 22 \\
2 \cdot 45 \\
0 \cdot 46\end{array}$ & $\begin{array}{r}1 \cdot 58 \\
9 \cdot 18 \\
10 \cdot 91 \\
2 \cdot 38\end{array}$ & $\begin{array}{l}0.66 \\
3 \cdot 85^{*} \\
4 \cdot 5^{8 * *}\end{array}$ \\
\hline
\end{tabular}

\section{DISCUSSION}

In our experiments $\mathrm{PP} / \mathrm{PP}$ did not mate slower than $\mathrm{AR} / \mathrm{AR}$ as found by Spiess and Langer (1964a). This could be due to variations in genetic background or to differences in experimental technique, since Spiess and Langer used a mating chamber with to pairs of flies for their experiments, and aged their flies for 6 days prior to mating at $15^{\circ} \mathrm{C}$., compared with the single pairs, aged apart for 4 days prior to mating in our experiments. Furthermore, their flies were all raised and tested at $25^{\circ} \mathrm{C}$. It is clear from these and other experiments that environmental variations will lead to large differences for behavioural characteristics. 
The importance of the karyotype of the female in determining mating frequency contrasts with the results of Kaul and Parsons (1965) who found the karyotype of the male to be of critical importance. However, Spiess and Langer $\left(19^{6} 4 b\right)$ found that the karyotype of the female was more important in determining mating speed over a one hour period in $D$. persimilis. In $D$. melanogaster Parsons (1965) found the genotype of the male to be more important for various combinations between inbred lines over a one hour period, although several experiments have shown that the female becomes progressively more important with time (Parsons, unpublished). If mating is to be regarded as an interaction between the copulation tendency of males and avoidance tendency of females (Fuller and Thompson, 1960), one might expect according to the intensities of these opposing tendencies, that the male would be more important in certain genotypic combinations and the female in others.

For duration of copulation, the karyotype of the male is clearly more important than that of the female in agreement with Kaul and Parsons ( 1965$)$. It is unlikely that copulation would cease before the sperm is transferred. This is presumably mainly male determined, so it is not unreasonable for the duration of copulation to be in general determined by the karyotype of the male.

The temperature $25^{\circ} \mathrm{C}$. is generally less favourable for mating than $20^{\circ} \mathrm{C}$. since the total mating frequency over 30 minutes is lower at $25^{\circ} \mathrm{C}$. This is reasonable as $25^{\circ} \mathrm{C}$. is close to the upper limit at which $D$. pseudoobscura can be maintained. In females, which is the sex important in determining mating frequency in these experiments, the fall in frequency affects the homokaryotypes only leading to the development of extreme heterokaryotype advantage.

If a short duration of copulation is selectively advantageous, which seems reasonable as those pairs completing copulation the most rapidly will leave genes in subsequent generations, then $25^{\circ} \mathrm{C}$. is less favourable than $20^{\circ} \mathrm{C}$. for this trait. The significant female $\times$ male interaction at $25^{\circ} \mathrm{C}$. is perhaps indicative of a breakdown of strict male determination expected for the duration of copulation, and may indicate a reduction in the efficiency of copulation. Furthermore, in males, which is the sex important in determining duration of copulation, the increase in duration affects the homokaryotypes much more than the heterokaryotypes, leading to slight heterokaryotype advantage at $25^{\circ} \mathrm{C}$.

Thus, considering the sex important in controlling mating frequency and duration of copulation, the heterokaryotypes vary less between temperatures than the homokaryotypes, i.e. the heterokaryotypes show a higher degree of homeostasis than the homokaryotypes. The differential effect of temperatures on the heterokaryotypes and homokaryotypes helps to explain the significant genotype $\times$ environmental interactions found in tables 2 and 5 .

Somewhat analogous results were found by Parsons (1959) in a 
study of larval survival of some inbred lines and their $\mathrm{F}_{1}$ 's in $D$. melanogaster under 6 different temperature regimes. The $\mathrm{F}_{1}$ 's were found to be substantially less variable between temperatures than the inbred lines, showing therefore more homeostasis in their adaptation to temperature and, as expected, the genotype $\times$ temperature interactions were smaller for the former. Among several other papers indicating the same general type of result is that of Dobzhansky and Levene (1955) on $D$. pseudoobscura, who showed that the viabilities of homozygotes of r9 different second chromosomes are more variable under a series of environments than the corresponding heterozygotes.

For mating frequency this heterokaryotypic stability between temperatures leads to extreme heterosis. Heterosis at extreme temperatures has been demonstrated several times for various fitness factors, e.g. larval survival in $D$. melanogaster (Parsons, 1959), relative viability in $D$. pseudoobscura (Dobzhansky, et al., 1955) and growth rates in Arabidopsis thaliana (Langridge, I962). This and other evidence is discussed by Langridge ( 1962 ) who maintains that heterosis under these circumstances is due to recessive, temperature-sensitive alleles occurring in natural populations which therefore lead to temperature sensitivity in homozygotes rather than in heterozygotes, although this seems to be an oversimplification.

This paper and Kaul and Parsons (1965) show that the two behavioural traits under investigation have properties similar to the various components of fitness more classically studied in $D$. pseudoobscura (e.g. Dobzhansky, 1957). Furthermore in D. melanogaster both these traits show reasonably high heritabilities (Parsons, 1964; MacBean and Parsons, unpublished), as do other behavioural traits in other organisms (Broadhurst, I96o; Broadhurst and Jinks, 1963). The difficulty in studying behaviour often revolves around finding an objective measure of the trait under investigation. This is perhaps one reason why the study of behavioural traits has lagged until recently. Another reason is that such traits are generally even more remote from the primary gene products than the quantitative morphological traits usually studied with the methods of biometrical genetics, which means that there may be frequent opportunities for large genotype environmental interactions.

\section{SUMMARY}

$\mathrm{r}$. The karyotype of the female is of predominant importance in the determination of mating frequency for all combinations between the karyotypes $\mathrm{AR} / \mathrm{AR}, \mathrm{AR} / \mathrm{PP}$ and $\mathrm{PP} / \mathrm{PP}$ at $20^{\circ} \mathrm{C}$. and $25^{\circ} \mathrm{C}$., although the karyotype of the male has some effect at $20^{\circ} \mathrm{C}$.

2. Duration of copulation is determined mainly by the karyotype of the male.

3. The temperature $25^{\circ} \mathrm{C}$., which is extreme for $D$. pseudoobscura, reduces the mating frequency and lengthens the duration of copulation for the homokaryotypes with little effect on the heterokaryotypes so 
that, in agreement with work on other fitness factors, the heterokaryotypes show more homeostasis between environments than the homokaryotypes.

4. There is extreme heterokaryotype advantage for mating frequency at $25^{\circ} \mathrm{C}$. in agreement with other fitness factors at extreme temperatures.

Acknowledgments.-D. K. wishes to acknowledge support from the Commonwealth of Australia Scholarship and Fellowship plan. We would also like to thank Dr J. A. Thomson for many helpful discussions and Miss Helen Gidley for technical assistance.

\section{REFERENCES}

BROADHURST, P. L. 196o. Experiments in psychogenetics. Applications of biometrical genetics to the inheritance of behaviour, I-102. In Eysenck, H. J. (Ed.), Experiments in Personality I. Psychogenetics and psychopharmacology. Routledge and Kegan Paul, London.

BROADHURST, P. L., AND JINKS, J. L. 1963. The inheritance of mammalian behaviour re-examined. 7. Hered., 54, $170-176$.

Dobzhansky, TH. 1957. Mendelian populations as genetic systems. Cold Spring Harbor Symp. Quant. Biol., 22, 385-393.

DOBZHANSKY, TH., AND LEVENE, H. 1955. Genetics of natural populations. XXIV. Developmental homeostasis in natural populations of Drosophila pseudoobscura. Genetics, $4^{\circ}, 797-808$.

DOBZHANSKY, TH., PAVLOVSKY, O., SPASSKY, B., AND SPASSKY, N. 1955. Genetics of natural populations XXIII. Biological role of deleterious recessives in populations of Drosophila pseudoobscura. Genetics, 40, 781-796.

FUlleR, J. L., AND thompson, w. R. 196o. Behavior Genetics. John Wiley, New York and London.

KAUL, D., AND PARSONS, P. A. 1965. The genotypic control of mating speed and duration of copulation in Drosophila pseudoobscura. Heredity, 20, 381-392.

LANGRIDGE, J. 1962. A genetic and molecular basis for heterosis in Arabidopsis and Drosophila. Am. Naturalist, 96, 5-27.

PARsons, P. A. 1959. Genotypic-environmental interactions for various temperatures in Drosophila melanogaster. Genetics, 44, I325-1333.

PARsons, P. A. 1964. A diallel cross for mating speeds in Drosophila melanogaster. Genetica, 35, 141-151.

PARsons, P. A. 1965 . The determination of mating speeds in Drosophila melanogaster for various combinations of inbred lines. Experientia, 2I, 478.

SPIESS, E. B., AND LANGER, B. 1964a. Mating speed control by gene arrangements in Drosophila pseudoobscura homokaryotypes. Proc. Natl. Acad. Sci., U.S., 5I, IOI5-1019.

SPIESS, E. B., AND LANGER, B. $1964 b$. Mating speed control by gene arrangement carriers in Drosophila persimilis. Evolution, 18, 430-444. 